\title{
Amino acid oxidation by young pigs receiving diets with varying levels of sulphur amino acids
}

\author{
BY KYU-IL KIM AND HENRY S. BAYLEY* \\ Department of Nutrition, University of Guelph, Guelph, Ontario NIG 2WI, Canada
}

(Received 13 January 1983 - Accepted 13 April 1983)

\begin{abstract}
1. Piglets were weaned at $3 \mathrm{~d}$ of age and were introduced to liquid diets in which $400 \mathrm{~g} / \mathrm{kg}$ protein was supplied as skim-milk powder and the balance as a mixture of free amino acids. The skim milk contributed $2 \cdot 3 \mathrm{~g}$ methionine and $1.4 \mathrm{~g}$ cystine $/ \mathrm{kg}$ diet; the experimental diets were made by supplementing these levels with free amino acids.

2. The adequacy of the test level of the amino acid in the diet was assessed by measuring the oxidation of $\left[1-{ }^{14} \mathrm{C}\right]$ phenylalanine as an indicator of the partition of the essential amino acids between incorporation into protein and degradation. Radioactivity recovered as carbon dioxide was used as a measure of catabolism.

3. Addition of $0.2,0.4,0.7,1.2$ and $1.7 \mathrm{~g} \mathrm{~L}$-methione/ $\mathrm{kg}$ to a diet containing $5 \mathrm{~g}$ cystine and $3 \mathrm{~g}$ choline chloride $/ \mathrm{kg}$ showed that phenylalanine catabolism was minimal for the diet with $2.7 \mathrm{~g}$ methionine $/ \mathrm{kg}$ indicating that this is the dietary requirement for methionine to serve as a source of methionine residues for protein synthesis.

4. Addition of D-methionine to produce a series of diets with graded levels of methionine showed that the D-isomer was less effective than the $\mathrm{L}$-isomer in reducing phenylalanine catabolism: the addition of $0.8 \mathrm{~g} \mathrm{D}-\mathrm{methionine} / \mathrm{kg}$ diet was needed to produce the same effect as $0.4 \mathrm{~g} \mathrm{~L}$-methionine $/ \mathrm{kg}$ diet showing that the replacement value of D-methionine for L-methionine was $50 \%$ in the young pig.

5. To investigate the influence of cystine on methionine requirement, diets with varying levels of methionine and cystine were prepared. Oxidation of $\left[\mathrm{U}^{14} \mathrm{C}\right]$ methionine was used as an indication of an excess of methionine, and the results showed that increasing the dietary methionine level above $3.0 \mathrm{~g} / \mathrm{kg}$ in diets containing $1.4 \mathrm{~g}$ cystine $/ \mathrm{kg}$ provided an excess of methionine for oxidation. This indicated a sulphur amino acid requirement of $4.4 \mathrm{~g} / \mathrm{kg}$, one-third of this being supplied as cystine.
\end{abstract}

Studies of the influence of graded levels of lysine in the diet on the release of ${ }^{14} \mathrm{CO}_{2}$ from tracer doses of $\left[{ }^{14} \mathrm{C}\right]$ lysine have been used to estimate dietary lysine requirements for sheep (Brookes et al. 1973) and for pigs (Chavez \& Bayley, 1976). The same technique has been used to estimate the dietary requirement of the rat for histidine and threonine (Kang-Lee $\&$ Harper, 1977, 1978). Increasing the dietary supply of the amino acid being investigated has no influence on the release of radioactivity as $\mathrm{CO}_{2}$ from tracer doses of the amino acid until a critical level is reached. Further increase in the supply of the amino acid above this level results in a linear increase in the release of radioactivity as $\mathrm{CO}_{2}$. The critical dietary level is interpreted as indicating that the amino acid supply at this point is neither deficient nor excessive.

Attempts to use this procedure to define methionine requirements have failed, both for rats (Aguilar et al. 1974) and for pigs (Fitzpatrick, 1977). In both instances, the relationship between loss of radioactivity in $\mathrm{CO}_{2}$ and dietary methionine level was curvilinear, showing that there was no critical dietary methionine level which influenced the rate of methionine catabolism. The wide variety of functions served by methionine, and the existence of two different catabolic pathways (Case \& Benevenga, 1976), apparently prevented a simple change from amino acid conservation to degradation as seen for lysine, histidine and threonine.

The observation that the oxidation of a second essential amino acid changes in response to the adequacy of the intake of another essential amino acid (Kim et al. 1983) prompted an investigation of methionine requirement using the oxidation of phenylalanine as an indicator of dietary methionine adequacy. To simplify the determination of methionine

$$
\text { * For reprints. }
$$


requirement, generous amounts of choline and cystine were provided in the diet to ensure that the requirement being measured was for the methionine needed to supply methionine residues for protein synthesis.

Previous attempts to measure the methionine requirement of the young pig have produced inconsistent results (Bowman, 1979); the use of DL-methionine in the experimental diets could explain these inconsistencies if the young pig did not fully utilize D-methionine. This possibility was examined by comparing the effectiveness of both $\mathrm{D}$ - and L-methionine in preventing the oxidation of the indicator amino acid. Methionine requirements estimated in the presence of generous levels of dietary cystine are of little practical use in diet formulation and so the interactions of dietary methionine and cystine levels on amino acid oxidation were also investigated to determine how much methionine could be replaced by cystine.

\section{EXPERIMENTAL}

The determinations were carried out using piglets of $10-14 \mathrm{~d}$ of age which had been weaned at $3 \mathrm{~d}$ of age and maintained in wire cages. The average weight of the piglets used in these studies was $1.76 \mathrm{~kg}$ at $3 \mathrm{~d}$ of age. They received a liquid diet in which $400 \mathrm{~g} / \mathrm{kg}$ protein was supplied as skim milk with the remaining $600 \mathrm{~g} / \mathrm{kg}$ being provided by a mixture of free amino acids. The diets used in the first two experiments contained $(\mathrm{g} / \mathrm{kg}): 8.0$ phenylalanine, 5 cystine, 3 choline chloride. Phenylalanine oxidation was used as the indicator of the adequacy of the methionine supply, the release of ${ }^{14} \mathrm{CO}_{2}$ in $1 \mathrm{~h}$ by the pigs after they had received an oral dose of $20 \mu \mathrm{Ci}\left[1-{ }^{14} \mathrm{C}\right]$ phenylalanine being used as a measure of its oxidation. Details of the diets and procedures are fully described by Kim et al. (1983).

The influence of varying the methionine concentration on phenylalanine oxidation was investigated in the first experiment using diets with methionine levels of $2 \cdot 3,2 \cdot 5,2 \cdot 7,3 \cdot 0$, 3.5 and $4.0 \mathrm{~g}$ methionine $/ \mathrm{kg}$ diet. Skim milk provided $2.3 \mathrm{~g}$ methionine $/ \mathrm{kg}$ and the remainder was added as L-methionine. Thirty-five piglets were used in the experiment.

The utilization of D-methionine was compared to that of $\mathrm{L}$-methionine in the second experiment. Thirty-six pigs received diets with $0 \cdot 2,0 \cdot 4,0 \cdot 6,0 \cdot 8,1 \cdot 2$ and $1 \cdot 7 \mathrm{~g} \mathrm{D}$-methionine $/ \mathrm{kg}$ in addition to the $2.3 \mathrm{~g}$ methionine $/ \mathrm{kg}$ provided by the skim milk. Another group of five pigs received the diet supplemented with $0.4 \mathrm{~g}$ L-methionine $/ \mathrm{kg}$. The oxidation of phenylalanine was measured for each pig as an indication of the adequacy of the methionine supply.

The objective of the third series of experiments was to examine the effects of varying dietary methionine levels with dietary cystine levels lower than those used in the first two experiments. The logical extension of the previous experiments was to measure ${ }^{14} \mathrm{CO}_{2}$ release from $\left[{ }^{14} \mathrm{C}\right]$ phenylalanine as an index of the adequacy of the dietary levels of the sulphur amino acids. The response was different from those in the previous experiments and precluded interpretation in terms of the dietary requirements of $\mathbf{S}$ amino acids. The succeeding experiments in this series were carried out to explore the interactions between dietary levels of methionine and cystine using ${ }^{14} \mathrm{C}$-labelled methionine and cystine.

These experiments were carried out without killing the piglets to measure the specific activities of the liver free amino acid, thereby allowing each piglet to be used more than once. Initially the oxidation of $\left[{ }^{14} \mathrm{C}\right]$ phenylalanine was measured for piglets receiving diets containing $2.7 \mathrm{~g}$ methionine $/ \mathrm{kg}$ and between 1.4 and $5.0 \mathrm{~g}$ cystine $/ \mathrm{kg}$. In the next experiment the oxidation of $\left[{ }^{14} \mathrm{C}\right]$ cystine was measured when the piglets received diets with a factorial arrangement of methionine levels $(2.7$ and $4.0 \mathrm{~g} / \mathrm{kg})$ and cystine levels $(1.4$ and $5.0 \mathrm{~g} / \mathrm{kg}$ ). The oxidation of $\left[{ }^{14} \mathrm{C}\right]$ methionine was then examined with piglets receiving diets containing $2.7 \mathrm{~g}$ methionine $/ \mathrm{kg}$ and $0.7,1.4$ and $3.6 \mathrm{~g}$ cystine $/ \mathrm{kg}$, the lowest level of cystine being provided using a diet in which skim milk supplied $200 \mathrm{~g} / \mathrm{kg}$ organic nitrogen and the 


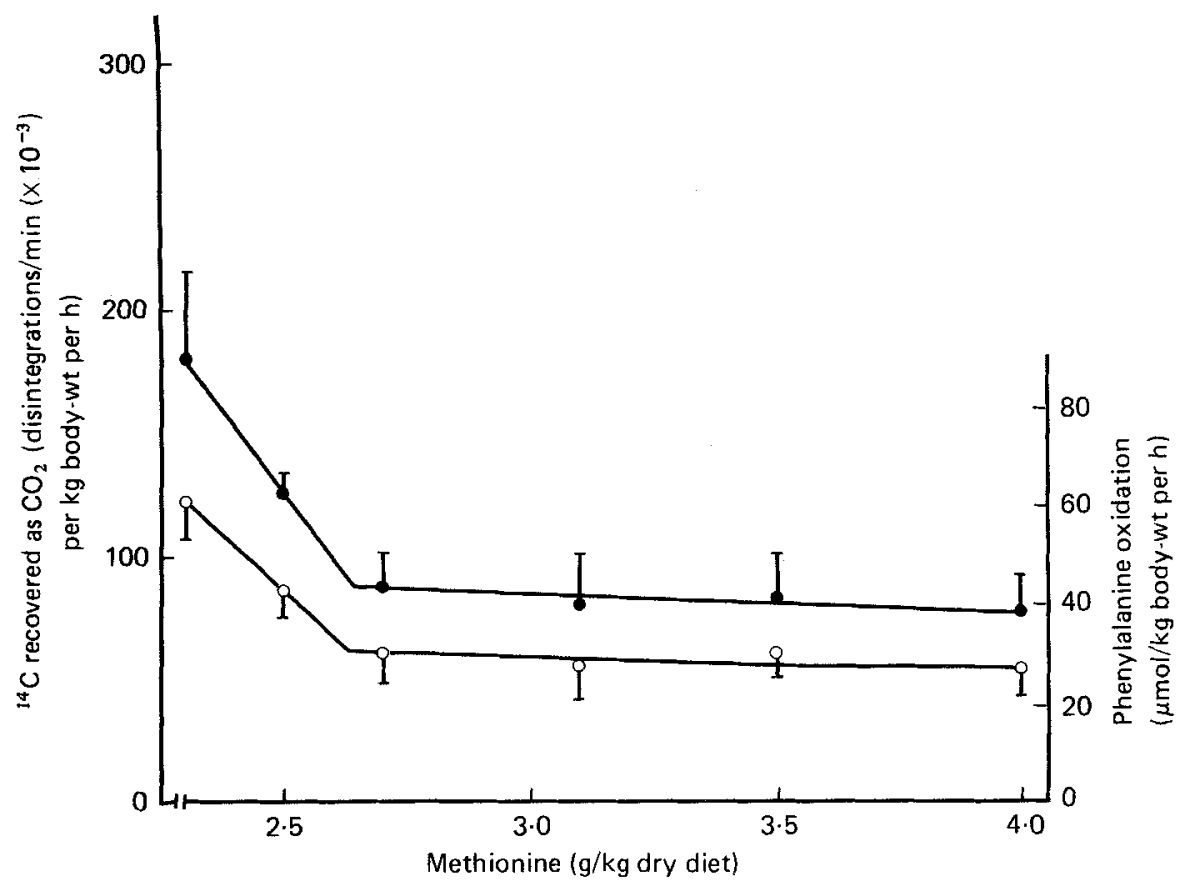

Fig. 1. Influence of dietary $\mathrm{L}$-methionine level on phenylalanine oxidation with dietary cystine level of $5 \mathrm{~g} / \mathrm{kg}$. Mean values with their standard errors represented by vertical bars for the radioactivity recovered as carbon dioxide (-_- ) and for phenylalanine oxidation $(\mathrm{O}-\mathrm{O})$ in $1 \mathrm{~h}$ by pigs which had received $20 \mu \mathrm{Ci} \mathrm{L-}\left[1-{ }^{14} \mathrm{C}\right]$ phenylalanine in diets containing graded levels of L-methionine. 'Broken-lines' were fitted by regression analyses; for both the $\mathrm{CO}_{2}$ recovery and for the phenylalanine oxidized the values for dietary methionine levels of $2 \cdot 3-2 \cdot 5 \mathrm{~g} / \mathrm{kg}$ diet were ascribed to the first part of the regression line. Points for $2 \cdot 3,2 \cdot 5,2 \cdot 7,2 \cdot 9,3 \cdot 5$ and $4 \cdot 0 \mathrm{~g} / \mathrm{kg}$ represent means for seven, five, five, five, six and six pigs respectively.

remainder was supplied by free amino acids. In the final experiment of this series the oxidation of $\left[{ }^{14} \mathrm{C}\right]$ methionine was measured in piglets receiving graded levels of methionine $(1 \cdot 2-6.0 \mathrm{~g} / \mathrm{kg})$ with a low level of cystine $(1.4 \mathrm{~g} / \mathrm{kg})$ : the lowest level of methionine was again achieved by using the diet in which skim milk provided only $200 \mathrm{~g} / \mathrm{kg}$ organic $\mathrm{N}$.

\section{RESULTS}

\section{Estimation of methionine requirement}

Fig. 1 shows that increasing the dietary methionine level from 2.3 to $2.7 \mathrm{~g} / \mathrm{kg}$ reduced the catabolism of $\left[{ }^{14} \mathrm{C}\right]$ phenylalanine, but further increases of the methionine level from 2.7 to $4.0 \mathrm{~g} / \mathrm{kg}$ had no effect on phenylalanine catabolism. This indicated that methionine was not limiting retention of other amino acids if present at more than $2.7 \mathrm{~g} / \mathrm{kg}$ diet. The specific activity of the liver free phenylalanine varied between 1.2 and $4.8 \times 10^{3}$ disintegrations $/ \mathrm{min}$ per $\mu \mathrm{mol}$ but was not influenced by dietary methionine level. Thus plots of both radioactivity recovered as $\mathrm{CO}_{2}$ and of phenylalanine oxidation rate $v$. dietary methionine level show the same pattern. Regression analysis of the results as described by Kim et al. (1983) showed that the cross-over point of the 'broken-line' plot relating ${ }^{14} \mathrm{CO}_{2}$ recovery to dietary methionine level occurred at a level of $2.64 \mathrm{~g}$ methionine $/ \mathrm{kg}(95 \%$ confidence limits $2.59-2.69 \mathrm{~g} / \mathrm{kg}$ ). The corresponding values for the plot relating phenylalanine oxidation to dietary methionine levels were $2 \cdot 64,(2 \cdot 48-2 \cdot 80) \mathrm{g} / \mathrm{kg}$. The pigs in the study 


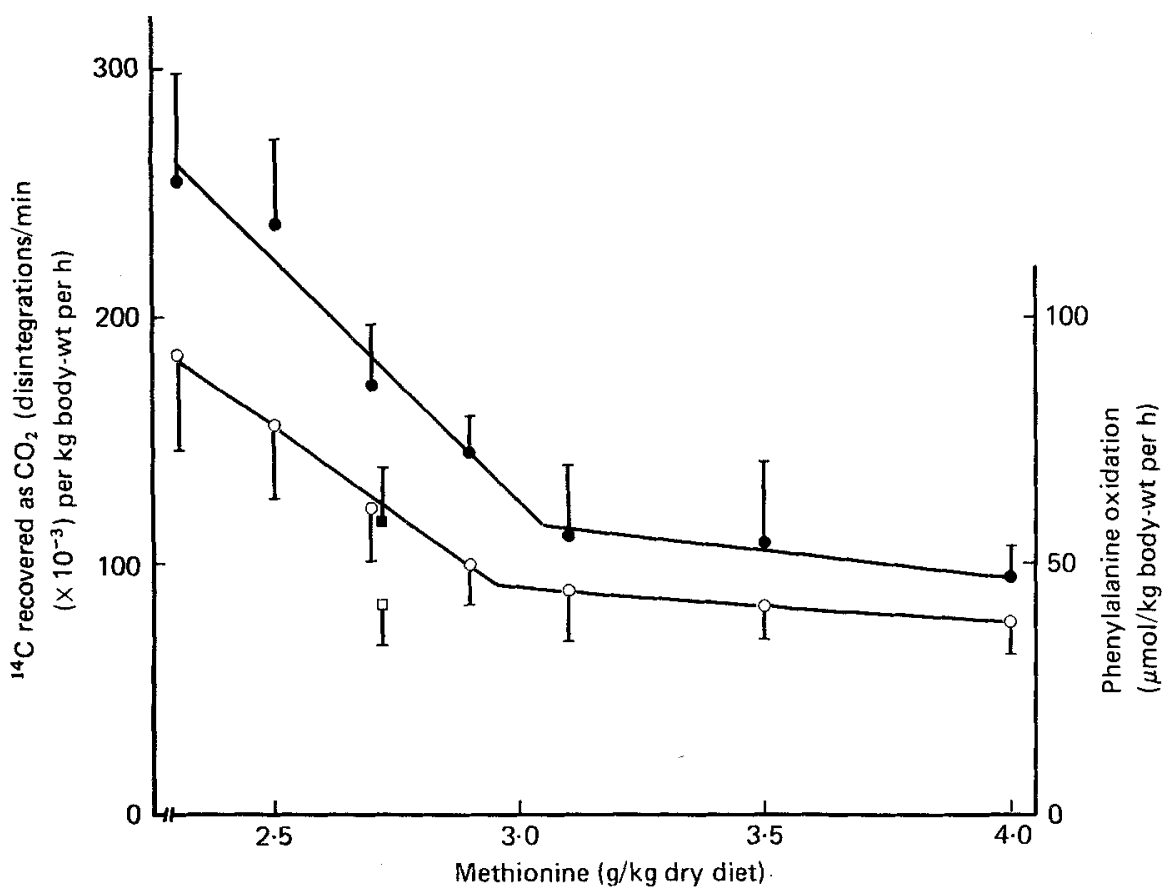

Fig. 2. Influence of supplementing a diet containing $2.3 \mathrm{~g}$ methionine $/ \mathrm{kg}$ with graded levels of D-methionine on phenylalanine oxidation. Mean values with their standard errors represented by vertical bars for the radioactivity recovered as carbon dioxide ( - $)$ and for phenylalanine oxidation $(\mathrm{O}-\mathrm{O}$ ) in $1 \mathrm{~h}$ by pigs which had received $20 \mu \mathrm{Ci}-[1-14 \mathrm{C}]$ phenylalanine in diets supplemented with graded levels of D-methionine. 'Broken-lines' were fitted by regression analyses; for both the $\mathrm{CO}_{2}$ recovery and for the phenylalanine oxidized the values for dietary methionine levels of $2 \cdot 3-2.9 \mathrm{~g} / \mathrm{kg}$ diet were ascribed to the first part of the regression line. Each point represents the mean for five or six pigs. One group of five pigs received a diet supplemented with $0.4 \mathrm{~g}$ L-methionine $/ \mathrm{kg}$ and the mean values with their standard errors for the radioactivity recovered as $\mathrm{CO}_{2}(\square)$ and for phenylalanine oxidation ( $\square$ ) are shown.

gained (mean with SE) 120 (7) g/d between $3 \mathrm{~d}$ of age and the day of the oxidation determined, and under these conditions the results show that the methionine requirement was $2 \cdot 7 \mathrm{~g} / \mathrm{kg}$ diet, in a diet containing $5 \mathrm{~g}$ cystine $/ \mathrm{kg}$ and $3 \mathrm{~g}$ choline $/ \mathrm{kg}$.

\section{Utilization of D-methionine}

Adding D-methionine to the diet in which skim milk contributed $2.3 \mathrm{~g}$ methionine $/ \mathrm{kg}$, reduced phenylalanine catabolism, showing that the piglets were able to utilize the D-isomer as a substitute for L-methionine (Fig. 2). Phenylalanine catabolism was minimized by the addition of either $0.8 \mathrm{~g} \mathrm{D}$-methionine $/ \mathrm{kg}$ or $0.4 \mathrm{~g} \mathrm{~L}$-methionine $/ \mathrm{kg}$ showing that the piglets used the D-isomer less effectively than the L-isomer. Regression analysis of the values in Fig. 2 showed a cross-over point for the 'broken line' plot for ${ }^{14} \mathrm{C}$ recovered as $\mathrm{CO}_{2}$ as a function of dietary methionine level of $3.03 \mathrm{~g} / \mathrm{kg}(2.96-3.11,95 \%$ confidence limits); the corresponding cross-over point for the phenylalanine oxidation was $2 \cdot 95(2 \cdot 73-3 \cdot 18) \mathrm{g} / \mathrm{kg}$. These results support those of the first experiment which showed a methionine requirement of approximately $3 \mathrm{~g} / \mathrm{kg}$ in a diet containing $5 \mathrm{~g} / \mathrm{kg}$ cystine and $3 \mathrm{~g} / \mathrm{kg}$ choline. The growth rate of the pigs in the present study between $3 \mathrm{~d}$ and the time-point of the oxidation determination was (mean with SE) $115(5) \mathrm{g} / \mathrm{d}$. 
Table 1. Radioactivity recovered as ${ }^{14} \mathrm{CO}_{2}$ from $L-\left[1-{ }^{14} \mathrm{C}\right]$ phenylalanine (disintegrations/ $\min \left(\times 10^{-3}\right)$ per $k g$ body-weight per $\left.h\right)$ for pigs receiving varying levels of sulphur amino acids

\begin{tabular}{cccccc}
\hline & \multicolumn{2}{c}{ Dietary level $(\mathrm{g} / \mathrm{kg})$} & & \\
& No. of \\
& Methionine & Cystine & observations & Mean & SE \\
\hline $2 \cdot 7$ & $1 \cdot 4$ & 4 & 213 & 26 \\
$2 \cdot 7$ & $2 \cdot 0$ & 5 & 181 & 28 \\
$2 \cdot 7$ & $3 \cdot 0$ & 5 & 139 & 37 \\
$2 \cdot 7$ & $4 \cdot 0$ & 5 & 180 & 16 \\
$2 \cdot 7$ & $5 \cdot 0$ & 1 & 135 & - \\
\hline
\end{tabular}

Table 2. Radioactivity recovered as ${ }^{14} \mathrm{CO}_{2}$ from $\mathrm{L}-\left[U^{14} \mathrm{C}\right]$ cystine (distintegrations per min $\left(\times 10^{-3}\right)$ per $\mathrm{kg}$ body-weight per $h$ ) for pigs receiving varying levels of sulphur amino acids (Mean values with their standard errors)

\begin{tabular}{|c|c|c|c|c|}
\hline & \multicolumn{4}{|c|}{ Cystine $(\mathrm{g} / \mathrm{kg})$} \\
\hline & \multicolumn{2}{|c|}{1.4} & \multicolumn{2}{|c|}{$5 \cdot 0$} \\
\hline$(\mathrm{g} / \mathrm{kg})$ & Mean & SE & Mean & SE \\
\hline $2 \cdot 7$ & 89 & 22 & 50 & 3 \\
\hline 4.0 & 99 & 2 & 94 & 22 \\
\hline
\end{tabular}

Table 3. Radioactivity recovered as ${ }^{14} \mathrm{CO}_{2}$ from $L-\left[U^{14} C\right]$ methionine (disintegrations per min $\left(\times 10^{-3}\right)$ per $k g$ body-weight per $\left.h\right)$ for pigs receiving varying levels of sulphur amino acids

\begin{tabular}{cccccc}
\hline \multicolumn{2}{c}{ Dietary level $(\mathrm{g} / \mathrm{kg})$} & & \\
& Methionine & Cystine & $\begin{array}{c}\text { No. of } \\
\text { observations }\end{array}$ & Mean & SE \\
\hline 2.7 & 0.7 & 3 & 16 & 9 \\
2.7 & 1.4 & 3 & 23 & 4 \\
2.7 & 3.6 & 2 & 43 & 16 \\
\hline
\end{tabular}

Influence of dietary cystine level on methionine requirement

The results of the experiment described in Table 1 show that increasing the cystine level from 1.4 to $5.0 \mathrm{~g} / \mathrm{kg}$ had no influence on the release of radioactivity as $\mathrm{CO}_{2}$ from $\left[{ }^{14} \mathrm{C}\right]$ phenylalanine. The radioactivity released as $\mathrm{CO}_{2}$ from $\left[{ }^{14} \mathrm{C}\right]$ cystine was not influenced significantly by the addition of either methionine or cystine to the diet (Table 2). These two experiments, although based on values from only a few pigs, suggest that the interaction between dietary levels of methionine and cystine on amino acid catabolism cannot be examined using the oxidation of either $\left[{ }^{14} \mathrm{C}\right]$ phenylalanine or $\left[{ }^{14} \mathrm{C}\right]$ cystine. Table 3 shows that increasing the level of cystine in the diet did not influence the oxidation of $\left[{ }^{14} \mathrm{C}\right]$ methionine; this observation indicates that it was not possible to examine the interaction of the two S-containing amino acids using the amino oxidation technique.

The results of the final experiment in this series (Fig. 3) show that feeding graded levels of methionine in diets containing $1.4 \mathrm{~g}$ cystine $/ \mathrm{kg}$ leads to the release of variable amounts 


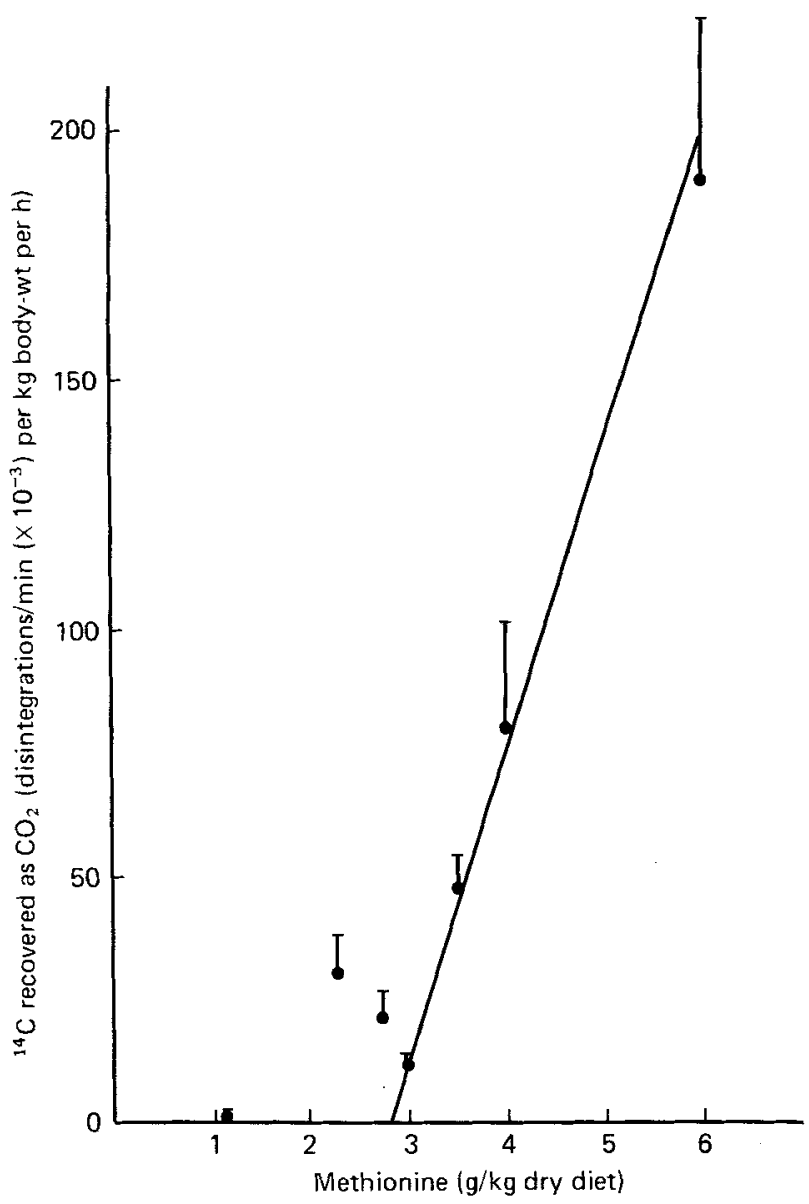

Fig. 3. Influence of dietary L-methionine level on methionine oxidation with dietary cystine level of $1.4 \mathrm{~g} / \mathrm{kg}$. Mean values with their standard errors represented by vertical bars for the radioactivity. recovered as carbon dioxide in $1 \mathrm{~h}$ by pigs which had received $20 \mu \mathrm{Ci} \mathrm{L}-\left[1-{ }^{14} \mathrm{C}\right]$ methionine in diets containing $1 \cdot 2,2 \cdot 3,2 \cdot 7,3 \cdot 0,3 \cdot 5,4 \cdot 0$ or $6 \cdot 0 \mathrm{~g}$ methionine $/ \mathrm{kg}$ and $1 \cdot 4 \mathrm{~g}$ cystine $/ \mathrm{kg}$. Regression line fitted for the dietary methionine levels of $3 \cdot 0-6 \cdot 0 \mathrm{~g} / \mathrm{kg}$ diet. Points represent means of three observations except for the diets containing $3 \cdot 0,3.5$ and $4.0 \mathrm{~g}$ methionine $/ \mathrm{kg}$ which are means of two observations.

of radioactivity as $\mathrm{CO}_{2}$ in diets containing less than $3.0 \mathrm{~g}$ methionine $/ \mathrm{kg}$, but that increasing the dietary methionine level from 3.0 to $6.0 \mathrm{~g} / \mathrm{kg}$ leads to a linear increase in the ${ }^{14} \mathrm{CO}_{2}$ production from $\left[{ }^{14} \mathrm{C}\right]$ methionine. These results indicate that the dietary methionine requirement is virtually unchanged by reducing the level of cystine from $4.6 \mathrm{~g} / \mathrm{kg}$ in the first experiment to $1.4 \mathrm{~g} / \mathrm{kg}$ in the present experiment.

\section{DISCUSSION}

The indirect studies of amino acid oxidation using phenylalanine as an indicator amino acid differentiated between deficient and sufficient levels of dietary methionine. This clear result contrasts with the failure of earlier studies to make this distinction using the effects of methionine supplementation on methionine oxidation.

DL-methionine has been used routinely to augment the $\mathbf{S}$ amino acid levels in diets for 
pigs on the assumption that both isomers are equally available. This has been validated for the rat (Berg, 1953). Cho \& Stegink (1979) showed that this was not due to the isomerization of the $\mathrm{D}$-isomer in the digestive tract of the rat because they found that parenterally-infused D-methionine was as effective as L-methionine. Cho et al. (1980) found that both isomers were used equally well by the neonatal miniature pig and the rabbit. The utility of the D-isomer for the chick is less clear; Katz \& Baker (1975) found that both the D- and L-isomers of methionine could be used equally well by growing chicks but later Baker \& Boebel (1980) showed that the chicks grew faster on diets supplemented with the L-isomer. There is clear evidence that D-methionine is not used as well as the L-isomer in primates, up to one-third of the ingested D-methionine being excreted in the urine of cynomolgous monkeys (Stegink et al. 1980). Similarly, in man a large part of the ingested D-methionine is excreted in the urine (Kies et al. 1975). Lunchick et al. (1978) used DL-methionine to supplement a diet for young pigs, considering that it was equivalent to only $80 \%$ of L-methionine, without documenting the basis for the statement.

The results of the current study, which show that D-methionine is utilized only half as effectively as the L-isomer in preventing the oxidation of another essential amino acid, may explain the discrepancies found amongst the methionine requirements previously estimated for piglets. D-Methionine which is not utilized for protein synthesis is not excreted in the urine. Bowman (1979) infused a tracer dose of ${ }^{14} \mathrm{C}$-labelled L- or D-methionine into piglets which were receiving diets supplemented with either $\mathrm{L}$ - or D-methionine and found that less than $1 \%$ of the dose was excreted in the urine. Deamination and consequent oxidation of the $\alpha$-keto $\gamma$-methiolbutyrate probably accounted for its disposal (Mitchell \& Benevenga, 1978).

The preliminary studies of the interaction of methionine and cystine failed to allow definition of the proportion of the total $S$ amino acid requirement which could be supplied as cystine. This may have been due to the unidirectional change from methionine to cystine which would result in low-cystine diets having relatively less effect on protein deposition than low-methionine diets, because the conversion of methionine to cystine would occur even if the dietary methionine levels were only just adequate.

Unfortunately the results of the direct determination of methionine requirement using ${ }^{14} \mathrm{CO}_{2}$ released from $\left[{ }^{14} \mathrm{C}\right]$ methionine by piglets receiving diets with graded levels of methionine did not allow the construction of a 'broken-line' plot to show the requirement, because of the inconsistencies of ${ }^{14} \mathrm{CO}_{2}$ release by the pigs receiving the diets with the lower levels of methionine. Although these inconsistencies preclude an estimate of 'requirement' with the precision of the indirect estimates in the first two experiments the results do confirm the conclusion that dietary levels of $3.0 \mathrm{~g}$ methionine $/ \mathrm{kg}$ and $1.4 \mathrm{~g}$ cystine $/ \mathrm{kg}$ are adequate to ensure minimum diversion of other amino acids to energy metabolism in the 2-week-old pigs.

This estimate that the $S$ amino acid requirement of the young pig is no more than $4.4 \mathrm{~g} / \mathrm{kg}$ is much lower than the $7.6 \mathrm{~g} / \mathrm{kg}$ listed by the (US) National Research Council (1979) for piglets of $1-5 \mathrm{~kg}$ live weight. Only $1.4 \mathrm{~g} / \mathrm{kg}$ could be provided as cystine, corresponding to one-third of the total, rather than the half suggested by the (US) National Research Council (1979). Confirmation of these low estimates of $S$ amino acids would entail growth studies using a basal diet containing less than $2.7 \mathrm{~g}$ methionine $/ \mathrm{kg}$ and $1.4 \mathrm{~g}$ cystine $/ \mathrm{kg}$ to allow correction of these deficiences by amino acid supplementation. Unfortunately the normal, rapid growth rates of piglets are only attained using milk-based diets and even providing as little as $100 \mathrm{~g}$ protein/ $\mathrm{kg}$ diet as skim milk would still result in a cystine level of $1.4 \mathrm{~g} / \mathrm{kg}$. Further reduction in the level of inclusion of skim milk severely reduces the growth rates of the piglets. Thus confirmation of the estimates awaits the development of suitable non-milk diets for baby pigs. 
Extension of these studies using amino acid oxidation as a means of indicating the adequacy of the diet with respect to $S$ amino acids may minimize the confusion in this area of pig nutrition which prompted Braude \& Esnaola (1973) to urge that nutritionists should refrain from making generalizations concerning the $S$ amino acid requirements of the pig.

This work was supported by the National Research Council of Canada, Agriculture Canada and the Ontario Ministry of Agriculture and Food. The authors are grateful for the skilled assistance of Joanne Reichertz.

\section{REFERENCES}

Aguilar, T. S., Benevenga, N. J. \& Harper, A. E. (1974). Journal of Nutrition 104, 761-771.

Baker, D. H. \& Boebel, K. P. (1980). Journal of Nutrition 110, 959-964.

Berg, C. P. (1953). Physiologial Reviews 33, 145-189.

Bowman, P. J. (1979). Metabolism of D-methionine in the piglet. MSc Thesis, University of Guelph.

Braude, R. \& Esnaola, M. A. (1973). British Journal of Nutrition 30, 437-445.

Brookes, I. M., Owens, F. N., Brown, R. E. \& Garrigus, U. S. (1973). Journal of Animal Science 36, 965-970.

Case, G. L. \& Benevenga, N. J. (1976). Journal of Nutrition 106, 1721-1736.

Chavez, E. R. \& Bayley, H. S. (1976). British Journal of Nutrition 36, 369-380.

Cho, E. S., Anderson, D. W., Filer, L. J. Jr. \& Stegink, L. D. (1980). Journal of Parenteral and Enteral Nutrition 4, 544-547.

Cho, E. S. \& Stegink, L. D. (1979). Journal of Nutrition 109, 1086-1093.

Fitzpatrick, D. (1977). Amino acid metabolism in the young pig. MSc Thesis, University of Guelph.

Kang-Lee, Y. A. \& Harper, A. E. (1977). Journal of Nutrition 107, 1427-1443.

Kang-Lee, Y. A. \& Harper, A. E. (1978). Journal of Nutrition 108, 163-175.

Katz, R. S. \& Baker, D. H. (1975). Poultry Science 54, 1667-1674.

Kies, C., Fox, H. \& Aprahamion, S. (1975). Journal of Nutrition 105, 809-814.

Kim, K. I., McMillan, I. \& Bayley, H. S. (1983). British Journal of Nutrition 50, 369-382.

Lunchick, C., Clawson, A. J., Armstrong, W. D. \& Linnerud, A. C. (1978). Journal of Animal Science 47, 176-183. Mitchell, A. D. \& Benevenga, N. J. (1978). Journal of Nutrition 108, 67-78.

National Research Council (1979). Nutrient Requirements of Domestic Animals, no. 2, Nutrient Requirements of Swine, 8th ed. Washington, DC: National Academy of Science.

Stegink, L. D., Moss, J., Printen, K. J. \& Cho, E. S. (1980), Journal of Nutrition 110, 1240-1246. 